\title{
Complexity, Ecologism, and Posthuman Politics
}

\begin{abstract}
Theorizations of the political in general, and international politics in particular, have been little concerned with the vast variety of other, non-human populations of species and 'things'. This anthropocentrism limits the possibilities for the discipline to contribute on core issues and prescribes a very limited scope for study. As a response to this narrow focus, this article calls for the development of a posthuman approach to the study of international politics. By posthuman, we mean an analysis that is based on complexity theory, rejects Newtonian social sciences and decentres the human as the object of study. We argue for a decentering of 'the human' in our scholarship as imperative to understanding the complexity of the world. However, this approach also has a political incentive, which we describe as 'complex ecologism'.
\end{abstract}

The term 'environment', as many critics have pointed out, is inadequate in that it reproduces a dualist understanding which sets the 'human' apart from other species, natures and entities and is grounded in the assumption that humans are not animals, or are an animal of a very special kind indeed. We will argue that by incorporating 'the environment' into the study of international politics as an 'issue' raising questions for security or governance, the separation of the 'human' from other species, natures and entities remains fixed, and the discipline continues to be anthropocentric. ${ }^{1}$ In order to move beyond anthropocentric International 
Relations, we draw on a range of bodies of theory: complex systems theory, ideas of posthumanism and the politics of complex ecologism. ${ }^{2}$

Theorizations within International Relations have been little concerned with the vast variety of other, non-human populations of species and 'things'. This has meant that scholarship has been narrowly focused and does not actually reflect the ways in which human social and political life is neither exclusively social, nor exclusively human but bound up with non-human beings and things. In this article therefore, we are particularly interested in exploring what happens to the study of politics if:

we took the "stuff" of politics seriously, not as a shorthand phrase for political activity but to signal instead the constitutive nature of the material processes and entities in social and political life, the way that things of every imaginable kind...help constitute the common worlds that we share and the dense fabric of relations with others in and through which we live $?^{3}$

This article argues for a decentering of 'the human' in our scholarship. Whilst some view this as scholarship in and of a 'new' reality in a technological age, ${ }^{4}$ we concur with those who suggest that 'our' human condition was ever populated with, by and in, other worlds of beings and things. ${ }^{5}$ The imperative of posthumanism is not just to develop tools for developing a understanding of human embeddedness in non-human animate and inanimate systems. We further suggest that a critical posthumanism is required. Like Cary Wolfe, we would hope that posthumanist scholarship might contribute to 'an increase in vigilance, responsibility and humility' that might accompany living in a world that is not understood humanocentrically. ${ }^{6}$

Certain accounts of posthumanism, which we prefer to distinguish from our perspective by labeling them 'transhumanism', strongly underplay the distinctive qualities apparent between human bodily existence and computer simulation, between organisms and 
cybernetic mechanisms. By contrast we consider that we must be attentive to distinction and boundaries, in addition to the overlapping and intersected qualities of social/natural/technical systems. There are important physical boundaries that distinguish humans and non-human animals from machines, and indeed, that also distinguish non-human animals from other nonhuman animals given the incredible variety in 'this vast encampment' of 'the Animal. ${ }^{7} \mathrm{We}$ need to take analytic account of both differences and distinctions as well as the ways in which beings and things (including ourselves, of course) are co-constituted.

In addition, the concept of the 'posthuman', as it is currently articulated, tends not to foreground forms of social power and domination. When we contend that theorizations should be critically posthuman in quality, we mean that they need to understand our human condition as embedded in and constituted with, relations and practices with other species. This does not mean that we underplay or neglect forms of intra-human exclusion and exploitation. Rather, we argue that the category 'human' is a social construct linked to formations of power that both set the 'human' apart from other species and also constitute discourses of forms of intra-human domination. Sets of historically situated discourses, religious or secular, reproduce the separation of man from matter - 'the anthropological machine,' as Giorgio Agamben describes it. ${ }^{8}$ The economical, social, and political formations of Western modernity have been constituted by and through constructions of social inequality, of class, race and gender, and these social categories of difference and domination have also been cross cut by prevailing ideas about 'nature' and the separation of the human from it. To this end we draw on ideas within a range of schools of political ecologism alongside re-workings of the idea of 'system' from complexity theory, to develop what we call 'complex ecologism' as a politics which contests both intra-human social injustice, alongside predominant forms of exploitative human relations with the non-human. This then is a thorough-going normative project which utilizes complexity theory to highlight the 
interactions between the human and non-human as a basis for re-considering the orientation of the study of International Relations.

Our argument is developed in the following four sections. First, we consider how reworkings of the notion of system in complexity theory can help us better theorize international politics in terms of international systems. Our perspective is to envisage international systems as open, comprised of multiple actors and embedded in a range of social, human, non-human and inanimate systems. Second, we move to a consideration of posthumanism, situating ourselves amongst more critical articulations such as are found in work in animal studies and political ecologism. Third, we consider how a posthumanist understanding of the world necessitates the recasting of many of the concepts that underpin 'the political', but note that many of the ideas currently on offer are insufficiently attentive to relations of power. Finally, we elaborate on the ways such relational power might be conceived through an ontology of 'complex ecologism'. The drawing together of complex systems, posthumanism and a critical politics of ecologism enables us to think about the politics of global life in terms of what we call 'posthuman international relations'. 9

\section{Differentiated Complexity and International Systems}

The most sophisticated account of international systems to date is found in the work of Barry Buzan and Richard Little, and we would largely agree with their prescription for International Relations as a 'failed intellectual project,' that the discipline needs to embrace systems theorizing and to adopt an 'holistic historical framework. ${ }^{10}$ However whilst we find much of value in their systems approach, our analysis of systems is somewhat different and leads us to ultimately different conclusions. Buzan and Little remain wedded to a Newtonian and human-centred account of the social world, whereas we advocate a post-Newtonian, complex, and non-human centred account. 
Such an account is principally enabled by the adoption of a complexity framework which informs different elements of our model of posthuman international relations. However introducing complexity theory to an International Relations audience is complicated not only by the associated terminology but also, and perhaps more significantly, by the variety of ways in which complexity has been understood and theorized. ${ }^{11}$ In short there is no 'one' complexity theory. Crucially, analyses in the social sciences inspired by complexity thinking have interpreted complexity in radically different ways with significant ontological and epistemological implications. ${ }^{12}$ A particular distinction can be drawn between those approaches that view complexity as a feature of models or metaphors (a majority view), and those that see complexity as ontologically real. While most authors argue that a complexity approach provides us with a means of interpreting the social world, they differ on what constitutes the relationship between theory and the social world. In short, is the complexity in the metaphor or model, or is there an underlying physics at work which impinges on the social world. Metaphoric approaches use ideas derived from the physical sciences and apply these to the social world 'as if' complexity was at work. ${ }^{13}$ Modelling approaches attempt to use computers to play out scenarios replicating complex phenomena. ${ }^{14}$ We consider that to regard complexity theory as a metaphor for understanding social phenomena is a weak position and one that reflects a human-centred approach, ignoring the embodied character of human systems and existence. Likewise modeling has understated the embedded character of human systems and represents, in Morin's words, a 'restricted complexity' which 'still attaches complexity as a kind of wagon behind the truth locomotive, that which produces laws' and 'avoids the fundamental problem of complexity which is epistemological, cognitive, paradigmatic. ${ }^{15}$ An alternative approach is to consider complexity in the social world as under-pinned by physics, with social systems overlapping and intersected by biological and physical systems. Some have advocated a consilient approach seeing physics 
'all the way down' ${ }^{16}$ While we would see complexity as ontologically real - by which we mean a property of, and observable across, a range of inanimate, animate, human and nonhuman systems - and hence more than a feature of metaphor and models. This said, we also acknowledge that, because of human cognitive capacities to represent, analyze and adapt, human social systems, while exhibiting complex characteristics, need specific forms of analysis. We advocate an approach to the study of complexity that we describe as 'differentiated complexity'.

A core idea from complexity thinking is the complex adaptive system. Systems from a complexity perspective refer to the boundaries which can be drawn around actors or units which have sufficient interactions to generate patterns, or emergent features. Boundaries in a complex system are open and porous in the sense that interactions between systems can impact on the character of internal inter-relationships - in other words complex systems do not have 'hard shells'. Stating the boundaries of complex adaptive systems are no less problematic than in any other attempt to define systems, though with regard to international relations states, the international political system and the international economic system can be considered as complex adaptive systems. ${ }^{17}$

Complex adaptive systems have a number of significant features. First, a central feature of complex adaptive systems is their propensity to develop in a non-linear fashion. To understand such systems therefore requires a break from a Newtonian conception of systems - one that has dominated systems thinking in the social sciences. Complex systems can behave in both linear and non-linear ways. In a linear system we would expect there to be a constant and predictable relationship between cause and effect. In International Relations theory, most models of the international system expect such a constant relationship between variables. In the work of Kenneth Waltz, for example, there was the expectation that there would be a regular relationship between the number of great powers and the characteristics of 
international relations. ${ }^{18}$ The democratic peace theory, seen as coming 'as close as anything we have to an empirical law in international relations, ${ }^{19}$ likewise points to a supposed regular linear relationship in international relations - democracies don't fight each other. In nonlinear systems there may be regularities but they are less likely to be durable. There is no predictable pattern in terms of the relationship between events, and there is no expectation that the same events will result in the same pattern of results.

Secondly, complex systems are in a constant state of flux, and are 'active and creative. ${ }^{20}$ In other words complex systems do not remain in a 'constant state' where the interactions between the parts can be modeled, as if their features were fixed. They are constantly changing, and in particular, over time have a propensity to become more complex. Complex systems develop in an organic fashion in that the interactions between the parts, and the character of their interactions, become increasingly multifaceted. In this process systems and agents change in ways that are not reversible. Complicating matters further, in complex systems feedback mechanisms are seen as central to the understanding of systems development. These characteristics of complex systems have considerable implications for the study of the social world. We have already argued that complex systems exhibit unpredictability. We would also argue that because of their actively creative features, it is the development of social systems that should be studied. There are links here with thinking about international relations from the perspective of Historical Sociology. Rather than seeing the international system, and international relations within it as essentially unchanging because of the determinant features of anarchy, which conditions states to act in certain ways, complexity theorists would argue that while international systems may be stable for a certain period of time self-organization, or 'autopoiesis' would be likely to result in changes in their character. $^{21}$ 
In terms of the analysis of complex systems of social relations, we are particularly drawn to the work of Sylvia Walby whose approach is perhaps the closest to our ‘differentiated complexity'. We draw considerable inspiration from Walby's analysis of systems, and in particular of intersectionality. Central to Walby's discussion is the question of how to analyze multiple forms of social inequality. Rather than focus on one form of social inequality, ${ }^{22}$ Walby seeks to understand how different forms of social inequality interact, or intersect with each other. These intersections occur within the broader context of globalization. As she notes, 'there is a need both to capture the distinctions, differentiations and nuances of complex inequalities... and to keep the global horizon in sight. ${ }^{23}$ In complexity theory she finds the toolbox to analyze these multiple systems. Hence, a key point of her work is to point out how developments in complexity theory permit a re-thinking of the concept of system. In particular, she argues that systems, when re-conceptualized from a complexity perspective, do not have an inherent tendency to move towards equilibrium. While feedback can be negative, drawing a system towards equilibrium, it can also be positive, reinforcing and amplifying forces for change. Systems, while having boundaries, also intersect with other systems, allowing the possibility of thinking about their mutual influence. However these intersections are always far from straightforward (or linear), and forms of inequality interact in ways that can only be understood from a complexity based analysis. Walby's model permits the analysis of unequal power relations between different systems, and her concern with intersecting forms of power reflects the concerns of feminist writers. ${ }^{24}$ Central to this is the concept of fitness landscape, which provides a way of understanding power differentials. Additionally it allows the analysis of the context in which actors operate, including the ability to manipulate the fitness landscape to the more powerful actors' advantage. ${ }^{25}$ Walby's approach is entirely humanocentric however and despite this detailed and effective account of relational and institutional complex systems, we need to 
examine the ways in which social systems attempt to exercise domination over the nonhuman world, and, at the same time, are co-constituted with and by them.

There are elements of International Relations theory, such as the work of Buzan and Little, or of historical sociologists that in focusing on historical patterns and systemic relations, are already open in some respects, to the use of a complexity approach. In thinking about complex systems, we have found it very useful to distinguish between different types. Here, we have drawn on the distinction between institutional, relational, and embodied social structure. ${ }^{26}$ We apply the same kinds of distinctions to complex systems. Drawing on a distinction between relational and institutional structures, for example, we can consider order in international systems as an emergent feature of relative distributions of power, and through the operation of institutions. One of the most significant features of international relations since 1945 has been the enormous proliferation of institutional order, in terms of organization, and restrictions on practice - we would argue that this is a manifestation of the increasing complexity of international institutional systems.

A further insight from complexity theory which serves as an important bridge to the second, posthuman strand of our argument is the way in which systems are perceived as interactive and co-constituted. Useful here is the notion of 'panarchy', taken from the work of Gunderson and Holling and their collaborators working in resilience studies. ${ }^{27}$ This draws in ecosystems, political, economic and social systems, alongside a notion of local, specific human cultural systems. Panarchies are living systems, conceived of as internally dynamic and historically non-static structures which develop mutually reinforcing relationships which are co-constitutive and adaptive. ${ }^{28}$ There are multiple connections established by feedback mechanisms between both different kinds of system, and different levels of a system. It is not only panarchies involving human systems which demonstrate decision making properties, rather a huge variety of non-human animals make collective decisions and engage in 
individual decision making behavior with a cumulate system effect. ${ }^{29}$ Living systems of humans, non-human animals and plants develop self-organized interactions with physical processes thus 'physics sets the constraints around which life structures opportunity. ${ }^{, 30}$ These self-organized interactions do not result in stability. Rather, systems may be vulnerable ecosystems may collapse or be undermined by human endeavors, political systems may be vulnerable due to the collapse of natural systems on which populations depend for resources, or social shifts. ${ }^{31}$ Importantly also, these configurations of systems in interaction are themselves complex systems with their own emergent properties. ${ }^{32}$

Eco-systems and human social systems are all complex systems in their own right. ${ }^{33}$ Whilst social and natural systems may be shaped and structured by similar processes, 'signification allows human systems to divorce themselves to some degree from space and time, the critical organizing dimensions of ecosystems. ${ }^{34}$ In addition, there is potentially increased dynamism as the reproduction of social systems means that they are more mutable. This does not mean that change operates towards self-regulation in terms of the maintenance of equilibrium. Whilst the notion of 'panarchy' in the work on resilience has origins in the study of ecology, it has moved more firmly into an examination of the detail of social system dynamics than most of the work in the study of 'global ecology'. The later, whilst paying some attention to quality of human life questions, is overwhelming focused on human impacts on 'natural' ecological systems. As such, it tends to separate the ecological conditions of existence from the organisation of human social life. ${ }^{35}$

Rather, as the resilience perspectives of Holling and others suggest, human systems may become more easily locked into paths of development that may have serious consequences for certain human and non-human populations. In addition, it is important to acknowledge the ways that human systems reproduce and develop formations of social power, of social relationships, which, like capitalism, patriarchy and so on, are usefully 
understood as complex adaptive systems. Holling et al. do not adequately account for the systemic patterns of human inequalities and it is this which gives us an added challenge in using complexity in social relations. There are systems of social power relations, ecosystems and various levels of systems and structure in the social world that give rise to a multiplicity of forms of local, regional, global configurations. The central contribution that students of international relations can make is to study the development of that system, its selforganising characteristics, and its relations to other human (such as capitalism, colonialism, patriarchy) and non-human (other species, the biosphere) systems. The embeddedness of systems is a key feature of differentiated complexity. International relations has always been about more than the mainstream script of the discipline of International Relations focused on relations between states. International politics has always been involved with the non-human and with global systemic relations of human and intra-human power. A posthuman approach is appropriate for the study of international relations because it enables us to think about politics in its embedded context with the non-human, and in terms of patterned relations of power. Before we outline the challenges of thinking about international politics through a posthumanist lens, it is necessary to specify exactly what we mean by 'posthumanism'.

\section{Posthumanism(s)}

The term 'posthumanism' has entered academic and popular discourse as a descriptor for critical perspectives on our human centrism. ${ }^{36}$ It suggests a perspective that seeks to understand more about the diversity of species and non-human beings with which our world is constituted. ${ }^{37}$ Thus the term 'animal' has been seen as ridiculously broad and impossible to deploy with any accuracy, whilst the way species are categorized has been critiqued as more

reflective of religious belief and political opinion, than physical or cognitive differences. ${ }^{38}$ In turn, the category human has always been differentiated - some humans are 'more human' 
than others in the sense that the 'animalizing' of certain groups of humans has been consitutive of forms of social exclusion and oppression such as those of gender and 'race'. 39 The social constitution of the 'human' has certainly impacted on non-human species and lifeworlds, usually regarded and utilized as means for the satisfaction of human ends. The term 'posthuman', however, is flexible, ambiguous and contested. In order to clarify our perspective and in this section we locate our position within a range of more and less critical perspectives.

Posthumanism has been associated with transhumanism, that is, the ideology that emphasizes the possible good of a future in which humans are able to acquire 'posthuman capacities' and extend their life and health spans, their capacities for happiness and their intellectual capabilities. ${ }^{40}$ Despite the appropriation of the term posthumanism by transhumanist advocates, these disembodied and transcendent fantasies are best seen as 'an intensification of humanism' and hence completely distant from the project of problematising human centrism. ${ }^{41}$

In sharp contrast, biophysical, philosophical and political posthumanisms centre on the relationships between human beings, other species and the whole other worlds of nonhuman 'nature'. A well-known example of what we might think of as biophysical posthumanism is the work of earth systems scientist, James Lovelock. In Lovelock's model, humans are utterly embedded in, and with, the multitude of systemic processes that make up the 'mega system' of the planet. Lovelock's fame is based on his development of the concept of Gaia: the idea that earth's multifarious living forms act as regulators that control conditions on the planet by a series of chemical feedbacks. ${ }^{42}$ Lovelock literally sees our future as posthuman in the sense that he thinks that the severity of the stresses humans have caused in the earth's system(s) mean that we have critically endangered the survival of humans and a vast number of other species. ${ }^{43}$ Fritjof Capra has linked this notion of the Earth 
as a complex system to the politics of ecologism. ${ }^{44}$ Here, humans are part of a multitude of various levels of natural and social systems, in which humans exploit other species and scapes as resources. Human activity has had such an impact that some have argued that we entered a new geological era. Simon Dalby employs the term 'anthropocene' (originally used by Crutzen and Stoermer) to describe a new geological age, in which humans have remade the 'circumstances of life' of both our own existence and that of all other species, with serious consequences for the survival of many life forms. ${ }^{45}$ These human induced changes mean that the environment is increasingly artificial - we have remade the environmental context of our own existence. Dalby's account is also influenced by certain kinds of political ecologism, and he considers our current predicament to be constituted through collective human activity that has been structured by carboniferous consumer capitalism, and relations between rich and poor regions and peoples. In such understandings, humanity is understood as locked into systemically exploitative relations to non-human lifeworlds, and also as socially intersectionalized. This kind of posthumanism is close to our notion of complex ecologism.

For those writing from within animal studies, such as Ralph Acampora and Cary Wolfe, we need to pay attention to human animality as well, and understand not only that we are one (animal) life form amongst a multitude, but also that, crucially, our biology and evolution are co-constituted with and by this multitude. ${ }^{46}$ Writers such as Wolfe emphasize that it is not so much 'the human' that is a difficulty, but the human-centric understanding of the human as the unique individual striving in the world, and not embodied and embedded in complex biotic lifeworlds. We would very much endorse Wolfe's understanding.

Less politically committed than these perspectives, but perhaps more engaged with established notions of 'politics', are a range of positions within science and technology studies and cultural studies, which want to move beyond an outdated understanding of the 
human in our current social, cultural and material context of technoscience. Most of these are very much influenced by the work of Bruno Latour who is keen to point out that we have never been purely human or 'animal' ${ }^{47}$ In the real natural/cultural world all kinds of hybrids are emergent. In this sense, we have never been modern, but rather we are 'a-modern'; the separation of nature and culture never was.

Widening the debate out further to include matter more generally, the political theorist Jane Bennett argues for a 'vital materialism'. This animating force is a character of matter itself, and Bennett's intention is to recognize the role of apparently inanimate matter affecting and configuring situations and events. ${ }^{48}$ Drawing on thinkers such as Spinoza, Thoreau and Adorno, Bennett's argument about the animism of all things, resonates in different ways, with the complexity understandings of Capra and of neuroscientists Humberto Maturana and Francisco Varela. ${ }^{49}$ The Spinozist notion of animate matter has also been foundational for systems inflected political ecologism, in particular, deep ecology. ${ }^{50}$ That complex adaptive interactions occur between animate and inanimate matter is indicated by research on early human tool and brain development. ${ }^{51}$ However, in vital materialism (and indeed, in deep ecologsim), there is a tendency to minimize the differences between subjects and objects with this notion of a vitality which runs through both human and non-human matter. The end in view is the development of a more environmentally aware and cautious politics, but the elevation of the 'shared materiality of all things' is a rather blunt instrument in securing this end. ${ }^{52}$

Following Deleuze and Guattari, ${ }^{53}$ Bennett develops the notion of assemblage in order, for example, to describe the multiple animate bodies of which an individual human body is constituted. We consider that the complexity notion of nested, overlapping or intersected co-evolved system(s) is more helpful. The latter allows us to differentiate and distinguish as well as examine the specific sites and forms of relation between the multiple 
organisms of a human body. It also presumes a contextualising array of systemic contexts in which a body might emerge. A sufficiently critical posthumanism must draw in the insights about human centrism, human power and social justice provided by elements within political ecologism and critical animal studies. We may never have been human, but our analyses of social relations have been human exclusive. Any attempt to transform international politics in a posthumanist direction must have questions of political power and relations with nonhumans at its core.

\section{Posthuman Politics}

Nation states and international organizations respond to the way we have harmed non-human matter, by incorporating the environment, the non-human lifeworld, into existing modes of the political - securitization and governance. This has been reflected in the discipline of International Relations by the development of environmental security and environmental governance as specific subfields. We have suggested elsewhere, that these approaches retain a traditional state-centred perspective in which 'the environment' is seens as threatened by, or

a threat to, human beings. ${ }^{54} \mathrm{~A}$ posthumanist perspective however, does not understand the environment as 'out there' but rather as 'with' and 'in here'. A key difficulty is that the spatial boundaries of the nation state deal poorly with non-human relations and our entanglements with other beings and things. Thom Kuehls has argued that such entanglements with biological life and non-human lifeworlds produce a topology that cannot be contained or understood within the current frameworks of nation states and international system. ${ }^{55}$ For Isabelle Stengers such political institutions are deeply problematic - we cannot reduce the inclusion of non-human worlds in politics to an account of the role they would play in political association and public life as currently constituted. ${ }^{56}$ This is because the very 
framing of those institutions was developed by mobilizing the category 'human' - our idea of what constitutes politics is human exceptionalist and exclusionist.

Allowing space in political life and political analysis for non-human beings and things however, would be radically trangressive for the tightly circumscribed discipline of politics and its smaller sibling, International Relations. There is a profusion of complex materials, systems and processes through and with which we humans live. We consider that a posthuman approach to politics involves the recasting of key debates around the subjects, actors and objects of politics, political representation, and possibilities for policy change.

The history of political theory has ascribed political will and agency to humans alone (or often, to very limited groups of humans). Even those contemporary thinkers with challenging and radical notions of the nature of decision making in democratic political institutions, consider that (human) speech is the medium of politics. ${ }^{57}$ Those political theorists with environmental credentials have also cast both technologies and 'natures' as outside of political life - as the objects of political attention rather than political agents with affect and causality. ${ }^{58}$ Those experimenting with radical notions of 'environmental democracy' have only experimented so far, and tend to conceive of politics as a humanexclusive sphere of activity and democratic decision-making that is separate from the objects over which democratic deliberation takes place. ${ }^{59}$

Bennett contests this humanocentrism with her notion of 'thing power. ${ }^{90}$ This enables us to see agentic capacity as distributed, and as distributed differently 'across a range of ontological types. ${ }^{91}$ In describing an electric grid as an assemblage of vital material and in her use of the term emergent properties, Bennett is actually close to the notion of a complex system. ${ }^{62}$ Such systems, or for Bennett, non-human assemblages, can act. However, what she actually means is something else - assemblages can have an impact or effect on humans and non-humans. Following on from this, she argues that human agency has never been separate 
from the non-human world, but always intermingled and co-constituted. Herein lays a recurrent problem in Bennett's work - a conflation between the idea of the properties and powers of beings and things, the notion of action and the idea of agency.

Margaret Archer argues that a defining characteristic of agency, as opposed to action, is that it is plural - agents are collectivities and actors are singular. ${ }^{63}$ Individual actors might reflect on their embodied situation and they might also recognize commonality. Individual actors may also possess will and intent. In animal studies, there have been suggestions that many non-human animals have agency because they have 'the capacity for self-willed action'. ${ }^{64}$ However, following Archer, Bob Carter and Nickie Charles consider that many non-human animals can be seen as agents to the degree that they share life chances and are affected by their social location. ${ }^{65}$ Considering this social location is of prime importance, for non-human animals are 'highly disadvantaged' in an anthropocentric distribution of resources. ${ }^{66}$ For Archer, to engage in anything beyond this primary agency, another emergent property is needed - political influence, associated with, for example, social movements. Carter and Charles further argue that language enables humans to change the world and their own place in it to such a degree that there is a fundamental asymmetry in the agency of human and non-human animals. ${ }^{67} \mathrm{We}$ are not convinced that there is sufficient understanding of forms of communication in other species to preclude animal agency, but concur with Carter and Charles that whilst many non-human animals might be agentic beings, they cannot usually exercise agency. ${ }^{68}$ Rather, where they exert political influence, this is via human representation in the form of social movement organizations or NGOs. This is fundamentally shaped by context - that of human domination over non-human animals.

The retort of those such as Bennett, Latour and Haraway, might be that unless we allow for the agency of things, and unless we decentre human language as an enabler of agency, we cannot decentre the human in political analysis. Bennett has rightly argued that 
the human/non-human dichotomy in political thought has not helped many of the political demands of humanism - the successful articulation of human rights claims, for example. ${ }^{69}$ Conversely however, there are serious questions to be raised about Bennett's assumption that a distributing concept of agency will be effective in unsettling humanocentric politics. ${ }^{70}$ Latour has argued that the powers and properties of non-human 'objects' call for a public space that is profoundly different from what is usually recognized as 'the political. ${ }^{71}$ In his view, a more fully democratic space recognizes that our collective public is not a body of human representatives of human interests, but a cosmos.

Latour wants to redefine the notion of the public and the idea of a political assembly. Whilst humans are held to be able to articulate views about the world, interests and 'wants', non-humans cannot and are thus held not to have interests, opinions and 'wants'. For Latour, the natural, technical world of non-human beings and things is represented, not by politicians but by professional experts, by 'science'. Science represents not the 'wants' of beings and things however, but 'facts' about them. Politicians, on the other hand, also represent, but are seen to represent views; claims and desires. ${ }^{72}$ For Isabelle Stengers this raises the problem of authority - there is power in both these kinds of representation, the representation of human wills and the representation of 'facts' about non-human worlds. ${ }^{73}$ Undergirding these ideas is the notion that political representation is an artifice. As Latour claims, it is a misrepresentation to say that 'the people' speak for themselves - they elect others who claim to speak in their name. ${ }^{74}$ What both Stengers and Latour propose is the idea of being the representatives of 'things' in the same assembly as the parliaments which claim to represent the wills of the 'people' - they want closer integration between scientific expertise and politics. We endorse the critique of the artifice of representation, although we consider that Latour's conception of representing non-humans is horizontal - there are incredible differences in properties, powers, affects, interests and even standpoints that fundamentally 
affect the politics of representing the 'non-human' in all its enormity. In addition, the representation of non-humans by scientists is not free from humanism, nor is it necessarily an extension of democracy as Latour suggests it would be.

James Brassett and William Smith have argued that the difficulties of deliberation are further exacerbated at the level of international politics. ${ }^{75}$ Whilst there have been many argument for the democratization of global governance and the increase of deliberation involving 'global civil society', opening up international organizations to such deliberation is contested and difficult. ${ }^{76}$ This is particularly so because of the way in which international political institutions and processes reflect systemic imperatives of relational power, such as that of capital. ${ }^{77}$ In opening up the international political arena to deliberation, it is interesting to see those similar problems of engagements through representation by elites (comparable to the professional scientists of Latour and Stengers) surfacing. For example, Brassett and Smith emphasize cultural interventions by NGOs. ${ }^{78}$

Environmental questions are subsumed under a bureaucratic rationality of resource managerialism by various nodes in the institutional system of international politics, be they local, national, regional or 'global' levels of governance. ${ }^{79}$ As Eva Lövbrand and Johannes Stripple note for example, the climate itself has become understood as an international political space, which is fundamentally shaped by local, national and international politics. ${ }^{80}$ The contemporary features of the 'carbon-cycle' are tied in to a logic of nation states operating territorially. The climate is also a space shaped by relational power - of capitalism, coloniality and other regimes of power and domination which are minimally disrupted by the elite political or scientific 'representation' of the interests of non-human beings and systems.

At present, it is difficult to see how we can get around the question of the problematic representation of non-human interests in politics, or whether in fact, 'representation' is a concept that can be utilized to this end. This said, we are not sure that the embedding of 
representation of the non-human by scientific elites, into political institutions will result in significant change. Such elite representation is already part of the national and international processes of making policies 'about' the 'environment'. However we would argue that an understanding of the world in terms of complex systems may enable less problematic policies to be made. We are seeing some changes, albeit limited ones, with patterns of decisionmaking becoming more participatory, involving a greater range of actors in particular NGOs, and a larger range of concerns (such as the 'environment', human rights, and animal rights). Policy makers at all levels in the institutional system are confronted with the complexity of socio-ecological issues, and a larger range of potential issues and side effects. Sandra Mitchell suggests a two-pronged approach to dealing with decision making in a complex world. She suggests that prediction should be replaced with models 'of multiple alternative futures' which evaluate different variables and possible policy effects. ${ }^{81}$ Others suggest that it is possible to go further, and to use the dynamics of complex systems in productive ways. ${ }^{82}$

From this brief discussion perhaps two general ideas could be derived. First, a precautionary principle. The study of complexity suggests that the possibilities for predicting the outcomes of certain policies are limited. This does not mean that all policies are doomed to failure, or that policy should not be made or implemented. However, 'we are not only failing to solve the persistent problems we face, but are in fact causing them. ${ }^{93}$ Policies, may have expected outcomes, however in complex systems, the unexpected should be anticipated, and hence the possible wider implications of policy options should be considered carefully before implementation. Morin argues that policy makers need a strategy, which he defines as 'the art of working with uncertainty. ${ }^{84}$ Second, a humility principle. Complexity approaches stress the character of over-lapping and inter-sectionalized systems. Human systems are embedded and co-exist with uncountable animate and inanimate systems. Developments and processes within one system can ripple through systems sparking different development 
trajectories. As Morin points out 'action escapes the will of the actor', entering not only wider human society, but also potentially into non-human systems. ${ }^{85}$

Policy makers need to avoid the 'arrogant dogmatism which rules non-complex forms of thinking", and accept the human situation of being embedded within a potentially enormous range of other systems. ${ }^{86}$ The latter, we would suggest, is difficult to envisage within the normative frameworks of politics where 'environmental' questions become matters of governance and securitization, and are conceptualized as threats to human populations. Here, we humans are often cast as at the mercy of non-human forces that must be regulated and controlled. This understanding of the human as separate from all other species and natural systems is fundamentally problematic for in complexity, ecosystems are complex systems and fundamentally affected by and co-constituted with, natural systems. In addition, however, re-envisioning the political to incorporate the representation of the 'facts', let alone the 'wants' of non-human beings and things is almost impossible to envisage in political institutions, at all levels, as currently constituted. Whilst we are co-constituted by and with the non-human, the implications of this for political organization are uncertain, but likely to necessitate radical change. ${ }^{87}$ There is not space in this article for suggesting what changes to current practices might be useful and possible. We do however want to suggest that changes must be significant. Whilst the posthuman politics of Latour and others provides a normative compunction to consider the non-human as bound up with the human condition of life, this critical ontology is more firmly established when integrated with insights from political ecologism, because this undertakes a thorough critique of the impact and power of human social organization on the non-human lifeworld. 


\section{Complex ecologism}

In the first two sections of this article, we made the argument that complex systems are ecologically embedded - we are caught up with multiplicities of species and things. We also considered that complex systems could be of different kinds - institutional, embodied and relational. Inter-human relations have been shaped by histories of distinction and domination, and at the same time have co-evolved with non-human systems. A complex and posthuman orientation to politics also requires an analysis of human centrism and human domination. The different schools of political ecologism have much to offer here, but they need reworking through the lens of complexity. Whilst complexity theory provides us with an overarching framework (of multiple, interrelated, co-constituted complex systems) it does not imply a normative position. Niklas Lumann is right to suggest that it is a 'meta-theory' ${ }^{88}$ Different political ecologisms have used the notion of 'system' to think about human relations with non-human systems, and have usefuly deployed ideas of domination and exploitation in so doing. In complexity models, all systems are bound up with others, and we suggest here that systems of social relations between both humans and other species and between different groups of humans are also usefully seen as complex systems.

Deep ecologism already adopts a systemic approach to understanding the organization and patterning of both social and natural life - it uses complexity as a framework for understanding relations between human and non-human systems. All processes are connected and human intervention in natural ecosystems cannot be without impact. Arne Naess suggests that living beings of all kinds are 'knots' in a biospherical field of relations. ${ }^{89}$ Such webs of relationships are incredibly complex and need to be understood as vast systems that interlock us with a variety of species and scapes. The net of relations is of paramount importance, and no 'system' is discrete, as Robyn Eckersley puts it: 
The world is an intrinsically dynamic, interconnected web of relations in which there are no absolute discrete entities and no absolute dividing lines between the living and the non-living, the animate and the inanimate, or the human and the non-human. ${ }^{90}$

It is unsurprising then, that deep ecologism and complexity theory have already been drawn together. ${ }^{91}$ In addition, a strength of deep ecologism is that it understands human society as structured in particular relations with the 'natural world', a system of relationships termed 'anthropocentrism'. Western society is human-centred in its organization and has a dominant worldview in which non-human natures are conceptualized in terms of means to human ends. However, anthropocentrism has been used in ways that marginalize human diversity and are blind to social inequalities. ${ }^{92}$ It has not been understood as a complex social system. Whilst we want to retain this notion of social relations with 'the environment' as systemic and exploitative, we also understand human relations with the environment as socially intersectionalized, that is, existent in a context of overlapping relations with other systems of social relations, such as those based on class, gender, and ethnic hierarchy.

A key insight of complexity approaches is the notion of self-organization - that order can arise without a specific orderer. Here there is a considerable overlap with anarchist contributions to the study of political ecology. In the work of Bookchin in particular, the analysis of various kinds of social hierarchies and forms of institutionalized social domination is key, and Bookchin's understanding of these as co-constitutive is highly compatible with a complexity understanding of social systems. Bookchin's contribution in turn, was highly influenced by the work of Peter Kropotkin. Both Bookchin and Kropotkin are significant for contemporary debates. This is, at least in part, because they consider the relationship between natural systems and social forms, and, in our view, they develop understandings of the world that are compatible with complexity approaches. In Bookchin's 
case, complexity is specifically referenced and critiqued $;{ }^{93}$ interestingly however, it is Kropotkin who might be read as more clearly a proto-complexity theorist.

Mutual Aid stressed the process of evolution as one where successful adaptation and exploitation of evolutionary niches is secured by species' propensity for co-operation and solidarity. ${ }^{94}$ This is very similar to 'symbiogenesis', a notion used extensively in complexity biology. ${ }^{95}$ Many of Kropotkin's ideas are elaborated in the work of Bookchin, who has been instrumental in linking anarchism to green social and political thought. The notion of overlapping and intersected forms of social domination which are systemic and coconstituting is clearly compatible with a complex systems analysis of social domination. In addition, Bookchin's understanding of the hybridized and amorphous nature of contemporary political systems embedded firmly in the social fabric and constantly in the processes of arranging and rearranging social life - maintaining themselves - can be given a complexity reading. ${ }^{96}$

Patterns of hierarchy and domination usurp, distort and reconfigure human relations, but also, particularly for Bookchin, structure our co-existence with non-human natures. Complexity theory, with its notions of co-existing, interrelated, multi-leveled and coconstituted systems enables the capture of the ontological depth of relational systems of social domination (of class, race, ethnicity, gender and so on) and their interaction or intersection. Here, socialist and feminist ecologisms have made important contributions. Peter Dickens suggests for example, that the nexus of environmental exploitation is the social organization of labour power in capitalist societies around the production of goods for the market. ${ }^{97}$ Indigenous and post-colonial ecologisms have stressed the ways in which ethnic hierarchy and exclusions and notions of race impact on the geography of environmental 'problems' and the vulnerabilities of certain populations. ${ }^{98}$ Further, a complexity reading of Marx has been developed by David Harvey in suggesting that local actions (for example, the 
exploitation of workers) reproduce the capitalist system and its emergent properties (for example, class relations, resource depletion) and give rise to various system contradictions (from social movements to environmental collapse). ${ }^{99}$ For various theorists, contemporary developments in capitalist relations means 'nature' becomes increasingly internal to the dynamics of capital accumulation as biotechnology is harnessed to overcome 'natural' barriers ${ }^{100}$ Thus Harvey suggests that we now have what he calls 'constructed ecosystems.' 101

Unfortunately, some writers in these fields are strongly antagonistic to feminist political ecologisms which are considered forms of reverse sexism, or positions which essentialize gender differences. ${ }^{102}$ Ecofeminism provides an analysis of the domination of nature as interrelated particularly with gender, but in many cases, also with a range of other forms of systemic inequalities. ${ }^{103}$ Ariel Salleh has emphasized that a rounded, 'triangulated' political ecologism would integrate the analysis of gender relations, north-south relations and those of capital, into an understanding of human relations with 'nature'. ${ }^{104}$ We see some of these feminist approaches as fully intersectionalized forms of social ecologism and compatible with a complexity analysis of multiple, co-evolved and dynamic systems of social relations. Ecofeminist analysis has tended to emphasize the systemic properties and effects of patriarchy, but would be enhanced by understanding systems of social relations of power, or social domination (such as patriarchy, capitalism, and the domination of the natural world) as analytically distinct but overlapping. It would also be strengthened by deployed complexity concepts in articulating how these relational systems are co-constituted with other systems of non-human beings and things. ${ }^{105}$

We take from deep ecologism that there is a social system of human domination, but consider that this takes historically and geographically specific formations. Such domination is linked to multiplicitious intra-human formations of domination, outlined in various ways 
by the different kinds of social ecologism. We conceive these systems as both analytically distinct, whilst being also, mutually constitutive. The domination of non-human nature is a system of exploitative relations that overlaps and interlinks with other systems of power and domination based on gender, capital, ethnic hierarchy and so on. This is what we call 'complex ecologism'. The politics of complex ecologism requires the interrogation and undermining of contemporary forms of social relations, both within and across species. It also requires that we understand international politics very differently.

\section{Conclusion: Posthuman International Relations}

What draws together different kinds of posthumanisms is the idea of the politics of 'life' - be it human or non-human. 'We,' the living, ${ }^{106}$ for example, are embedded in a carbon cycle that international politics seeks increasingly to regulate. Our embodied and embedded condition in a world of multiple species and systems which operate at multiple levels from domestic relations in the home to the regulation of the temperature of the planet, raise deep problems for politics based on the fictive constructs of nation states. Yet in the contemporary world, nation states are multiplying and many are strengthening. Even in the face of anthropogenic climate change, the politics of states assert themselves in regional and global policy for as Lövbrand and Stripple note:

...the 1997 Kyoto Protocol to the Climate convention opens up the inclusion of land-based carbon sinks as a way for states to comply with their emission reduction targets. In less than fifteen years, the international climate discourse has rearticulated global carbon flows as "national sinks". ${ }^{107}$

Vital materialists such as Stengers argue that we cannot have a politics that is not attached to a cosmos - we need to articulate a 'cosmopolitics' to reflect our more-thanhuman condition. ${ }^{108}$ The complexity theorizing of Edgar Morin suggests a similarly 
cosmological understanding of the co-constituted lifeworld of social and natural systems. ${ }^{109}$ We would not disagree, but we do think these are utopian texts.

The world of politics, national and international, is an artifice, just at Latour suggests. It cannot capture the cosmological reality of life on this planet and attempts by institutions of human governance to regulate life, since the eighteenth century in particular, have remade a world in deeply problematic ways. Thom Keuhls has argued that the space of ecopolitics must be beyond sovereign territory. ${ }^{110}$ Currently, it is not, and we are faced with the biopolitics of nation states and the international institutional system of states attempting to regulate life with such problematic consequences. The notion of bio-regionalism, developed in the 1970s, remains a pipedream; notions of 'environmental citizenship' poorly describe the identities of human citizens and the speaking, human political subject remains a foundational discourse of 'the political'.

International Relations has not been particularly imaginative when attempting to broaden its repertoire to include 'the environment' and thus has an additive approach to the non-human lifeworld. 'Environmental issues' are understood as problems which might be attended to within the existing frameworks of securisation and governance. Perhaps if International Relations - a discipline so pre-occupied with territory and borders - can move more firmly into explaining international politics in terms of systems, preferably complex ones, and not just institutional ones, it might better grasp the politics of the world in which we live. That world, as complexity theory suggests, is not divided into territories in which bounded societies of humans live under singular political authority and in the context of discrete 'natural environments'. The politics of posthumanism urges us to attend to the realities of our situation in a world where we are all made up of multiple species and things. International Relations has demonstrated, at least at its margins, the growth of critical positions on its state-centrism. This has been particularly driven by feminist scholarship and 
the attempt to broaden the actors and 'populations' of study - to women of course, and also more recently, to children. The realization of an International Relations which better appreciates the ways in which our world is teeming with multiple human and non-human lives, relations and formations of being, represents a more fundamental challenge.

A complexity approach to international politics that takes into account the worlds beyond the human species, requires an understanding of social, political and economic relations as impacting beyond the human and as co-constituted by elements of non-human and human systems. In considering systems of social relations as complex and intersectionsised, we are not forced into the 'either/or' dichotomy that has driven deep ecologists into dispute with other forms of political ecologism. As relational systems are coconstituted, we need to account for both human domination of non-human lifeworlds and intra-human inequalities. In complex ecologism, these cannot be separated out. Thus we argued for a political position of complex ecologism, which attempts to account for social intersectionality and various kinds of power relations. This article has asserted the need for rethinking the boundaries of 'the political' in the light of our posthuman being in the world; our condition as co constituted with myriad other beings and things. We have used complexity theory in order to develop a critical ontology - complex ecologism - that can examine social formations of power in relation to intra-human social differences and patterns of human domination over non-human systems. In addition, it understands human relations and social institutions as embodied and co-constituted within systems involving a multiplicity of beings and things. Posthumanism and complex ecologism demand a different way of seeing what international relations might be. Whilst we have many disagreements with Latour, we endorse his understanding of the social world as ever implicated with nonhumans. If International Relations wants to be relevant to understanding the complexity of the political world, it will have a posthuman future. ${ }^{111}$ 
${ }^{1}$ For a discussion of anthropomorphism related to issues of environmental security see XXXX (Reference omitted for anonymity).

${ }^{2}$ For the purposes of this article, we use the terms international politics and international relations interchangeably. International Relations is used to describe the discipline which focuses on global processes, while international relations and international politics refer to the constituent features of those processes.

${ }^{3}$ Bruce Braun and Sarah J. Whatmore, 'The Stuff of Politics: An Introduction', in Bruce Braun and Sarah J. Whatmore (eds), Political Matter: Technoscience, Democracy and Public Life, (Minneapolis: University of Minnesota Press, 2010), p. ix.

${ }^{4}$ See Neil Badmington, Alien Chic: Posthumanism and the Other Within (London:

Routledge, 2004); Andrew Barry, Political Machines: Governing a Technological Society (London: Anthone Press, 2001).

${ }^{5}$ As argued by Bruno Latour. See We Have Never Been Modern (Hemel Hempstead: Harvester Wheatsheaf, 1993); Reassembling the Social: An Introduction to Actor-Network Theory (Oxford: Oxford University Press, 2005).

${ }^{6}$ Cary Wolfe, What is Posthumanism? (Minneapolis, MN: University of Minnesota Press, 2010), p. 47.

${ }^{7}$ Jacques Derrida, 'The Animal That Therefore I am (More To Follow)', Critical Enquiry 28:2 (2002), p. 339.

${ }^{8}$ Giorgio Agamben, The Open: Man and Animal, trans. Kevin Attell, (Stanford, CA:

Stanford University Press, 2004).

${ }^{9}$ These arguments will be developed more comprehensively in XXXX (Reference omitted for anonymity). 
${ }^{10}$ Barry Buzan and Richard Little, 'Why International Relations has Failed as an Intellectual Project and What to do About it', Millennium, 30:1 (2001), p. 19.

${ }^{11}$ For an excellent discussion of complexity theory within International Relations see Emilian Kavalski, 'The Fifth Debate and the Emergence of Complex International Relations Theory: Notes on the Application of Complexity Theory to the Study of International Life', Cambridge Review of International Affairs, 20:3 (2007), pp. 435-454. We elaborate some complexity concepts related to international relations in XXXX (Reference omitted for anonymity).

${ }^{12}$ We have argued elsewhere that there are at least four different ways in which complexity ideas have been adopted in the social sciences. See XXXXX (Reference omitted for anonymity).

${ }^{13}$ See, for example, John Urry, Global Complexity (Oxford: Polity, 2003).

${ }^{14}$ This is primarily associated with the work of network analysts. See Duncan Watts, Small Worlds: The Dynamics of Networks Between Order and Randomness (Princeton NJ: Princeton University Press, 1999).

${ }^{15}$ Edgar Morin, (2007) 'Restricted Complexity, General Complexity’ in Carlos Gershenson, Diederik Aerts, and Bruce Edmonds (eds), Worldviews, Science and Us: Philosophy and Complexity (Singapore: World Scientific Publishing, 2007), p. 10.

16 The classic statement on consilience is Edward O. Wilson, Consilience: The Unity of Knowledge (London: Abacus, 1999). Also see Frijtof Capra The Hidden Connections: A Science for Sustainable Living, (London: Harper Collins, 2002).

${ }^{17}$ The differences between the Waltzian conception of system and complexity approaches is discussed in XXXXX (Reference omitted for anonymity). For a more general discussion of the distinction between 'Newtonian' and complex systems see Robert Ulanowicz, 'Ecology: A Dialogue between the Quick and the Dead', Emergence, 4, no. 1/2 (2002): 34-52. 
${ }^{18}$ Kenneth N. Waltz, Theory of International Politics (New York: Random House, 1979), pp. 134-138.

${ }^{19}$ Jack S. Levy, 'Domestic Politics and War', Journal of Interdisciplinary History, 18:4 (1988), p. 662.

${ }^{20}$ Gulbenkian Commission, Open the Social Sciences: Report of the Gulbenkian Commission on the Restructuring of the Social Sciences (Stanford, CA: Stanford University Press, 1996), p. 61 .

${ }^{21}$ Autopoiesis refers to the self-organizing propensities of complex systems. Walby, for example, states that in complex systems this 'process of self-reproduction of a system is selforganizing and self-defining. The system has internal processes that internally connect and reproduce the system.' See Walby, Globalization and Inequalities: Complexity and Contested Modernities (London: Sage, 2009), p. 51.

${ }^{22}$ A traditional form for the analysis of social inequality would be class relations.

${ }^{23}$ Sylvia Walby, Globalization and Inequalities, pp. 2-3.

${ }^{24}$ See, for example Nira Yuva-Davis 'Intersectionality and Feminist Politics', European Journal of Women's Studies, 13: 3 (2006): 193-209.

${ }^{25}$ The term 'fitness landscape' is taken from biology, and in particular the work of Stuart Kauffman. See, in particular, Stuart Kauffman, (1993) The Origins of Order: Self Organization and Selection in Evolution (Oxford University Press, 1993). While there are justifiable concerns in importing such an analysis from biology to the study of the social world, it has been applied to the study of a variety of human social world situations. See, for example, Lee Fleming and Olav Sorenson, 'Technology as a Complex Adaptive System: Evidence from Patent Data', Research Policy, 30:7 (2001), pp. 1019-1039; Ralph Stacey, Complexity and Creativity in Organizations (San Francisco, CA: Berrett Koehler, 1996). 
${ }^{26}$ This useful distinction is made by José López and John Scott, Social Structure

(Buckingham: Open University Press, 2000).

${ }^{27}$ Lance H. Gunderson and C.S. Holling (eds), Panarchy: Understanding Transformations in Human and Natural Systems (Washington, DC: Island Press, 2002).

${ }^{28}$ C.S. Holling, Lance H. Gunderson and Garry D. Peterson, 'Sustainability and Panarchies', in Lance H. Gunderson and C.S. Holling (eds), Panarchy: Understanding Transformations in Human and Natural Systems (Washington, DC: Island Press, 2002), pp. 72-74.

${ }^{29}$ Holling, Gunderson and Peterson, 'Sustainability and Panarchies', pp. 85-87.

${ }^{30}$ Holling, Gunderson and Peterson, 'Sustainability and Panarchies', p. 88.

${ }^{31}$ For example, economic exploitation, changes in population levels, increased literacy rates.

${ }^{32}$ C.S. Holling, Stephen R. Carpenter, William A. Brock and Lance H. Gunderson,

'Discoveries for Sustainable Futures', in Lance H. Gunderson and C.S. Holling (eds),

Panarchy: Understanding Transformations in Human and Natural Systems (Washington,

DC: Island Press, 2002), p. 411.

${ }^{33}$ Marten Scheffer, Frances Westley, William A. Brock and Milena Holmgren, 'Dynamic Interaction of Societies Ecosystems: Linking Theories from Ecology, Ecology and Sociology', in Lance H. Gunderson and C.S. Holling (eds), Panarchy: Understanding Transformations in Human and Natural Systems (Washington, DC: Island Press, 2002), p. 210.

${ }^{34}$ Frances Westley, Stephen R. Carpenter, William A. Brock, C.S. Holling and Lance H. Gunderson, 'Why Systems of People and Nature are not Just Social and Ecological Systems', in Lance H. Gunderson and C.S. Holling (eds), Panarchy: Understanding Transformations in Human and Natural Systems (Washington, DC: Island Press, 2002), pp. 108-9.

${ }^{35}$ See for example, Charles H. Southwick, Global Ecology in Human Perspective (Oxford: Oxford University Press, 1996). The edition of the current issue of the journal Global 
Ecology and Biogeography (21:2) illustrates this point well, with articles focused, for example, on the negative impact of human social life on lizards, spiders and amphibians. Whilst this is the general tendency, there is some work by human geographers which links global ecology to social inequality and politics structures, see Valerie de Campos Mello 'Mainstreaming the Environment: Global Ecology, International Institutions and the Crisis of global Governance', Human Ecology Review, 7:1 (2000), pp. 31-45.

${ }^{36}$ Badmington, Alien Chic.

${ }^{37}$ Nicholas Gane, 'When We Have Never Been Human, What is to be Done? An Interview with Donna J. Haraway', Theory, Culture and Society, 23:7-8 (2006), p. 140.

${ }^{38}$ The problematising of the category 'animal' is often associated with the late work of Jaques Derrida, The Animal That Therefore I Am, edited my Marie-Louise Mallet, translated by David Wills (New York: Fordham University Press, 2008); whilst the difficulties with anthropomorphizing non-human animals is illustrated well by Donna J. Haraway, Primate Visions: Gender, Race and Nature in the World of Modern Science (London: Routledge, 1989).

${ }^{39}$ Recent comments in Britain about a 'feral underclass' being a case in point. See Ken Clark, 'Punish the Feral Rioters, but Address our Social Deficit too', The Guardian, 5 September 2011, p. 34. For a detailed discussion of constructions of humanity see Joanna Bourke, What it Means to be Human: Reflections from 1791 to the Present (London: Virago, 2011); for a link between this and posthuman perspectives, see Wolfe, What is Posthumanism? The animalization of humans is a theme in feminist and postcolonial literatures, see for example Val Plumwood, Feminism and the Mastery of Nature (London: Routledge, 1993).

${ }^{40}$ Nick Bostrom, 'Human Genetic Enhancement: A Transhuman Perspective', Journal of Value Inquiry, 37:4 (2003), pp. 493-506.

${ }^{41}$ Wolfe, What is Posthumanism?, p. xv. 
${ }^{42}$ James Lovelock, Ages of Gaia: A Biography of our Living Earth, $2^{\text {nd }}$ edn, (Oxford: Oxford University Press, 2000).

${ }^{43}$ As is somewhat dramatically argued in James Lovelock, The Vanishing Face of Gaia: A Final Warning (London: Allen Lane, 2009).

${ }^{44}$ See Fritjof Capra, The Web of Life: A New Synthesis of Mind and Matter (New York: Harper Collins, 1996); The Hidden Connections.

${ }^{45}$ Simon Dalby, Security and Environmental Change (Cambridge, UK: Polity Press, 2009), pp. 11-12; Paul Crutzen and Eugene Stoermer, 'The "Anthropocene", Global Change Newsletter 41 (2000), pp. 12-13.

${ }^{46}$ See, for example Ralph R. Acampora, Corporeal Compassion: Animal Ethics and Philosophy of Body (Pittsburg, PA: University of Pittsburg Press, 2006); Cary Wolfe, Animal Rites: American Culture, the Discourse of Species and Posthumanist Theory (Chicago, IL: Chicago University Press, 2003).

${ }^{47}$ Latour, We Have Never Been Modern.

${ }^{48}$ Jane Bennett, Vibrant Matter: A Political Ecology of Things (Durham, NC: Duke University Press, 2010).

${ }^{49}$ See Capra, The Web of Life. Humberto Maturana and Francisco Varela argue for a dispersed notion of cognition, see for example, Autopoiesis and Cognition: The Realization of the Living (Kulwer Academic, Dordrecht, 1980); The Tree of Knowledge: The Biological Roots of Human Understanding (Boston, MA: Shambhala, 1987).

${ }^{50}$ See Arne Naess, 'The Shallow and the Deep, Long-Range Ecology Movement: A Summary', Inquiry, 16:1 (1973), pp. 95-100; Robyn Eckersley, Environmentalism and Political Theory: Toward an Ecocentric Approach (London: University College London Press, 1992). 
${ }^{51}$ Aldo Faisa et al (2010) 'The Manipulative Complexity of Lower Paleolithic Stone Toolmaking', PLoS ONE 5(11): e13718, available at http://www.plosone.org/article/info\%3Adoi\%2F10.1371\%2Fjournal.pone.0013718. ${ }^{52}$ Bennett, Vibrant Matter, p. 13.

${ }^{53}$ Giles Deleuze and Félix Guattari, A Thousand Plateaus: Capitalism and Schizophrenia, trans. Brian Massumi, (Minneapolis, MN: University of Minnesota Press, 1987). The idea of assemblages has also been developed by Manuel DeLanda. See his A New Philosophy of Society: Assemblage Theory and Social Complexity (London: Continuum, 2006).

${ }^{54}$ XXXXX (Reference omitted for anonymity).

55 Thom Kuehls, Beyond Sovereign Territory: The Space of Ecopolitics (Minneapolis, MN: University of Minnesota Press, 1996).

${ }^{56}$ Isabelle Stengers, 'Including Nonhumans in Political Theory: Opening Pandora's Box?', in Bruce Braun and Sarah J. Whatmore (eds), Political Matter: Technoscience, Democracy and Public Life (Minneapolis: University of Minnesota Press, 2010), p. 7.

${ }^{57}$ In particular Jürgen Habermas. See his 'Three Normative Models of Democracy', in Seyla Behabib (ed.), Democracy and Difference: Contesting the Boundaries of the Political (New York: Columbia University Press, 1996), pp. 21-30. More specifically from an International Relations perspective the work of Andrew Linklater, has been influenced by Habermas' work. See, for example, The Transformation of Political Community: Ethical Foundations of the Post-Westphalian Order (Oxford: Polity, 1998); 'Dialogic Politics and the Civilising Process', Review of International Studies 31:1 (2005), pp. 141-154.

${ }^{58}$ See, for example, Nikolas Rose, Powers of Freedom: Reframing Political Theory (Cambridge, UK: Cambridge University Press, 1999); Andrew Dobson and Derek Bell, 'Introduction' in Andrew Dobson and Derek Bell (eds), Environmental Citizenship (Cambridge, MA: MIT Press, 2006), pp. 1-20. 
${ }^{59}$ Andrew Dobson and Robyn Eckersley (eds), Political Theory and the Ecological

Challenge (Cambridge, UK: Cambridge University Press, 2006).

${ }^{60}$ Jane Bennett, 'The Force of Things: Steps toward an Ecology of Matter', Political Theory, 32:3 (2004), pp. 347-72. Bennett draws on Latour's notion of an 'actant', which can be a human or non-human source of action. See Bruno Latour, The Politics of Nature: How to Bring the Sciences into Democracy, trans. Catherine Porter (Cambridge, MA: Harvard University Press, 2004), p. 75.

${ }^{61}$ Bennett, Vibrant Matter, p. 9.

${ }^{62}$ See, in particular, Bennett, Vibrant Matter, pp. 24-28.

${ }^{63}$ Margaret S. Archer, Being Human: the Problem of Agency (Cambridge, UK: Cambridge University Press, 2000), p. 261.

${ }^{64}$ Sandy Irvine, If You Tame Me: Understanding our Connections with Animals (Philadelphia PA: Temple University Press, 2004).

${ }^{65}$ Bob Carter and Nickie Charles, 'Human-animal Connections: An Introduction', in Bob Carter and Nickie Charles (eds), Human and Other Animals: Critical Perspectives

(Basingstoke: Palgrave, 2011), pp. 1-29.

${ }^{66}$ Carter and Charles, 'Human-animal connections', p. 11.

${ }^{67}$ There is a parallel here with the argument that the self-organizing properties of intra human systems outstrip those of natural systems. See Frances Westley et al. 'Why systems', pp. 1045.

${ }^{68} \mathrm{We}$ are aware that this is a most controversial point, and the problem of the 'catch-all' concept 'animal' makes itself felt. However whilst Carter and Charles are right to emphasise the importance of speech in articulating human social power, it is important to acknowledge that some other species have sophisticated means of communication, and exhibit culture (evidenced in shared symbolic meaning, ritual and practices and socialisation of diversity in 
cultural patterns). See Marc Bekoff's work on 'listening' to and 'hearing' a variety of nonhuman animals and the problems of representing them, Minding Animals: Awareness, Emotions and Heart (Oxford: Oxford University Press, 2002).

${ }^{69}$ Bennett, Vibrant Matter, p. 12.

${ }^{70}$ Bennett, Vibrant Matter, pp. 36-37.

${ }^{71}$ Bruno Latour, 'From Real Politik to Dingpolitik: or How to Make Things Public', in Bruno Latour and Peter Weibel (eds), Making Things Public: Atmospheres of Democracy

(Cambridge, MA: MIT Press, 2005), p. 15.

${ }^{72}$ Latour, The Politics of Nature, p. 148.

${ }^{73}$ Isabelle Stengers, The Invention of Modern Science, trans. Daniel W. Smith, (Minneapolis MN: University of Minnesota Press, 2000), p. 84.

${ }^{74}$ Latour, The Politics of Nature, p. 148.

${ }^{75}$ James Brassett and William Smith, 'Deliberation and Global Civil Society: Agency, Arena, Affect', Review of International Studies, 36:2 (2010), pp. 413-430.

${ }^{76}$ James Bohman, Democracy Across Borders: From Demos to Demoi (Cambridge, MA: MIT Press, 2007).

${ }^{77}$ John S. Dryzek, Deliberative Global Politics: Discourse and Democracy in a Divided World (Cambridge, UK: Polity Press, 2006).

${ }^{78}$ Brassett and Smith, 'Deliberation and Global Civil Society', pp. 425-430.

${ }^{79}$ See Timothy W. Luke, Capitalism, Democracy and Ecology: Departing from Marx (Champaign, IL: University of Illinois Press, 1999).

${ }^{80}$ Eva Lövbrand and Johannes Stripple, 'The Climate as a Political Space', Review of International Studies, 32:2 (2006), pp. 234-5.

${ }^{81}$ Sandra Mitchell, Unsimple Truths: Science, Complexity and Policy (Chicago, IL: University of Chicago Press, 2009), p. 90. 
${ }^{82}$ Robert Axelrod and Michael Cohen suggest three main inter-linked ways in which advantage can be taken of complexity. First, building variation into policy options increases the number of options that can be explored, and allows more successful options to be pursued, when certain possibilities fail. Second, the effectiveness and robustness of a system can be increased by promoting interaction amongst its units, and thereby enhancing variety and increasing the options to deal with uncertain circumstances, and interaction by building links within and across systems. The third element, is building the capacity to select the most appropriate options. See, Robert M. Axelrod and Michael D. Cohen, Harnessing Complexity: Organizational Implications of a Scientific Frontier (New York: Free Press, 1999), pp. 155158.

${ }^{83}$ John D. Sterman, 'All Models Are Wrong: Reflections on Becoming a Systems Scientist', System Dynamics Review, 18:4 (2002), p. 504.

${ }^{84}$ Edgar Morin, On Complexity (Cresskill, NJ: Hampton Press, 2008), p. 96.

${ }^{85}$ Morin, On Complexity, p. 96.

${ }^{86}$ Morin, On Complexity, p. 97.

${ }^{87}$ This is left unresolved here, the focus of our argument is the need for the re-invention of political organisation and practices. The specific kinds of reinvention are the focus of our current work.

${ }^{88}$ Niklas Lumann, Social Systems (Cambridge, UK: Cambridge University Press, 1995). Luhmann would object to our argument that a normative position is required, and would see his systems theory as non-normative. Yet Luhmann's use of complexity is embedded in Parsonian functionalism. The multiple and varied uses of complexity frameworks by different kinds of theory (Marxism, postmodernism, ecologism and so on) suggest that despite Lumann's objections, complexity alone will not suffice. 
${ }^{89}$ Arne Naess, Ecology, Community and Lifestyle: Outline of an Ecosophy (Cambridge, UK: Cambridge University Press, 1989).

${ }^{90}$ Eckersley, Environmentalism and Political Theory, p. 49.

${ }^{91}$ Capra, The Hidden Connections.

${ }^{92}$ Robyn Eckersley, 'The Discourse Ethic and the Problem of Representing Nature', Environmental Politics, 8:2 (1999), p. 38.

${ }^{93}$ Bookchin's point is that complexity approaches fail to catch the 'indeterminacy' of the social world. See, Bookchin, The Philosophy of Social Ecology (Montréal: Black Rose Books, 1990), p. 151. While we would accept that the social world is different, it is the capacity of complexity theory to provide us with the tools to understand that indeterminacy that makes it significant.

${ }^{94}$ Roel van Duyn, Message of a Wise Kabouter (London: Duckworth, 1969), p. 21.

${ }^{95}$ See, for example, Lynn Margulis and Dorion Sagan, Acquiring Genomes: A Theory of the Origins of Species (New York: Basic Books, 2002); also Scott F. Gilbert, 'The Genome in its Ecological Context: Philosophical Perspectives on Interspecies Epigenesis', Annals of the New York Academy of Science, 981:1 (2002), pp. 202-218.

${ }^{96}$ Murray Bookchin, The Ecology of Freedom: The Emergence and Dissolution of Hierarchy (Edinburgh: AK Press, 2005), pp. 191-200.

${ }^{97}$ Peter Dickens, Reconstructing Nature: Alienation, Emancipation and the Division of Labour (London: Routledge, 1996).

${ }^{98}$ See Ramachandra Guha, The Ramachandra Guha Omnibus (Oxford: Oxford University Press, 2004); Vandana Shiva, Soil not Oil: Climate Change, Peak Oil and Food Insecurity (London: Zed, 2008).

${ }^{99}$ David Harvey, Justice, Nature, and the Geography of Difference (Oxford: Blackwell, 1996), p. 187. 
${ }^{100}$ Noel Castree, 'Marxism, Capitalism and the Production of Nature', in Noel Castree and Bruce Braun (eds), Social Nature: Theory, Practice and Politics (Oxford: Blackwell, 2001), p. 191.

${ }^{101}$ Harvey, Justice, Nature, and the Geography of Difference, p. 187.

${ }^{102}$ See the discussion of 'anti-man' stances in David Pepper, (1993) Eco-Socialism: From Deep Ecology to Social Justice (London: Routledge, 1993), p. 148. By contrast 'essentialist eco-feminism' suggests that 'poor women [are] intrinsically closer to nature.' See Juan Martinez-Alier, 'From Political Economy to Political Ecology', in Ramachandra Guha and Juan Martinez-Alier (eds) Varieties of environmentalism: Essays North and South (London: Earthscan, 1997), p. 36.

103 The following provide good examples: Mary Mellor Breaking the Boundaries: Towards a Feminist Green Socialism (London: Virago, 1992); Maria Mies Patriarchy and Accumulation on a World Scale (London: Zed Books, 1986); Val Plumwood Feminism and the Mastery of Nature (London: Routledge, 1993).

${ }^{104}$ Ariel Salleh, 'Ecological Debt: Embodied Debt', in Ariel Salleh (ed.) Eco-Sufficiency and Global Justice: Women Write Political Ecology (London: Pluto Press, 2009), pp. 3-5. ${ }^{105}$ See Erika Cudworth, Developing Ecofeminist Theory: The Complexity of Difference (Basingstoke: Palgrave, 2005).

${ }^{106}$ Or, for Bruno Latour, 'earthlings'. See, Bruno Latour 'A Plea for Earthly Sciences', in Judith Burnett, Syd Jeffers, and Graham Thomas (eds), New Social Connections: Sociology's Subjects and Objects (Basingstoke: Palgrave, 2009), p. 75.

${ }^{107}$ Lövbrand and Stripple 'The Climate', p. 218.

${ }^{108}$ Isabella Stengers, Cosmopolitics I, trans. Robert Bononno, (Minneapolis, MN: Minnesota University Press, 2010).

${ }^{109}$ Morin, On Complexity. 
${ }^{110}$ Kuehls, Beyond Sovereign Territory.

111 The case that different perspectives require a different view of what are the subjects, objects and processes of international politics has been well established by feminist interventions. See for example, Christine Sylvester, 'Woe or Whoa! International Relations where it's not supposed to be', Brown Journal of World Affairs, 10:2 (2004), pp. 57-68. 